\title{
Endosymbiont-free ants: Molecular biological evidence that neither Wolbachia, Cardinium or any other bacterial endosymbionts play a role in thelytokous parthenogenesis in the harvester ant species, Messor barbarus and $M$. capitatus (Hymenoptera: Formicidae)
}

\author{
Paloma MARTíneZ-ROdRÍGUeZ ${ }^{1}$, Jonás SARASA ${ }^{1}$, Begoña PeCO ${ }^{2}$, Berta M. JAUREGUI ${ }^{3}$, Desiree RiverA ${ }^{2}$ \\ and Jose L. BELLA ${ }^{1}$ \begin{abstract}
Spain; e-mails: paloma.martinez@uam.es; jonas.sarasa@uam.es; bella@uam.es
${ }^{2}$ Departamento de Ecología, Facultad de Ciencias, Universidad Autónoma de Madrid, C/ Darwin 2, E-28049 Madrid, Spain; e-mails: begonna.peco@uam.es; desi.rivera@gmail.com

${ }^{3}$ Servicio de I+D+i. Obrascón Huarte Lain S.A., Po de la Castellana 259D, Torre Espacio, 28046 Madrid, Spain; e-mail: berta7punto@yahoo.es
\end{abstract} \\ ${ }^{1}$ Departamento de Biología (Genética), Facultad de Ciencias, Universidad Autónoma de Madrid, C/ Darwin 2, E-28049 Madrid,
}

Key words. Wolbachia, Cardinium, Spiroplasma, endosymbionts, Formicidae, Messor, thelytokous parthenogenesis

\begin{abstract}
Thelytokous parthenogenesis is a type of sex determination in which females are produced from unfertilized eggs. Genetic and endosymbiont-induced forms of thelytoky have been described in the Hymenoptera. Our study has revealed that Wolbachia, Cardinium, Spiroplasma and other endosymbionts are probably absent in Iberian populations of harvester ants, Messor barbarus and Messor capitatus (Hymenoptera: Formicidae: Myrmicinae) and are thus not involved as factors in the sex determination of these two species. Our results lend weight to previous suggestions that bacterial parthenogenesis induction in Hymenoptera is probably limited to the reproductive systems of chalcidoid and cynipoid parasitoid wasps (Hymenoptera: Apocrita: Chalcidoidea and Cynipoidea, respectively).
\end{abstract}

\section{INTRODUCTION}

Arrhenotoky is a characteristic haplodiploid sexdetermining system present in most Hymenoptera species, including ants, bees and wasps, in which females are produced from fertilized eggs and males from unfertilized ones (Fig. 1a-c), whilst thelytokous parthenogenesis, in which females are produced from unfertilized eggs, has been characterized in some 1,500 species, including insects, annelids, reptiles, Urodela and fishes (White, 1984), but has only been described in a few species of Hymenoptera (Fig. 1d-f) (Rabeling \& Kronauer, 2013) In most of thelytokous Hymenoptera for instance, unfertilized eggs produce diploid female offspring by fusion of meiotic products, enabling this thelytokous species to survive through several generations of females, without males or sexual reproduction (Fig. 2) (Rabeling \& Kronauer, 2013).

In ants (Hymenoptera: Apocrita: Formicidae), thelytoky has been reported in some species like including Cataglyphis piliscapa (Forel) (author names needed for all Latin names cited; see http://www.antweb.org/ description.do?genus $=$ cataglyphis\&name $=$ piliscapa $\&$ rank =species) (Lenoir \& Cagniant, 1986), Pristomyrmex pungens (Mayr) (Itow et al., 1984; Tsuji, 1988), Cerapachys biroi (Forel), Platythyrea punctata (Smith) (Schilder et al., 1999), Vollenhovia emeryi (Wheeler) (Ohkawara et al., 2006, Okamoto \& Ohkawara, 2009), Wasmannia auropunctata (Roger) (Fournier et al., 2005, Foucaud et al., 2007; Fournier \& Aron, 2009; Rey et al., 2011), Mycocepurus smithii (Forel) (Himler et al., 2009, Rabeling \& Kronauer, 2011), Cerapachys biroi (Forel) (Kronauer et al., 2012) and Messor capitatus (Latreille) (Grasso et al., 1998). Of these species, there are found to be three thelytokousy reproductive strategies involved (Himler et al., 2009; Rabeling et al., 2011), characterised by: (i) ants species such as $P$. pungens, $C$. biroi, $P$. punctate and $M$. capitatus, whose workers produce females but tend to lose their queen (Pearcy et al., 2004); (ii) ants species such as $V$. emeryi, $W$. auropunctata and Cataglypsis cursor (Fonscolombe) whose mated queens produce workers sexually and queens asexually (Pearcy et al., 2004; Fournier et al., 2005; Ohkawara et al., 2006); and (iii) ant species such as M. smithii whose workers are sterile and queens are strictly thelytokous individuals (Himler et al., 2009).

Cytogenetic mechanisms leading to thelytokous diploidization can be divided into meiotic and post-meiotic modifications (Vavre et al., 2004; Pearcy et al., 2006; Adachi-Hagimori et al., 2008) (see Fig. 2 for mechanisms). Apart from the parthenogenetic system, the detailed causes and cytological processes involved in sex determination in Hymenoptera are not totally resolved and, in many cases, are species-specific (Wenseleers \& Billen, 2000). The best-known model of sex determination in Hymenoptera is the complementary sex determination system (CSD), in which diploid males are only produced by inbreeding. In this model revealed by 


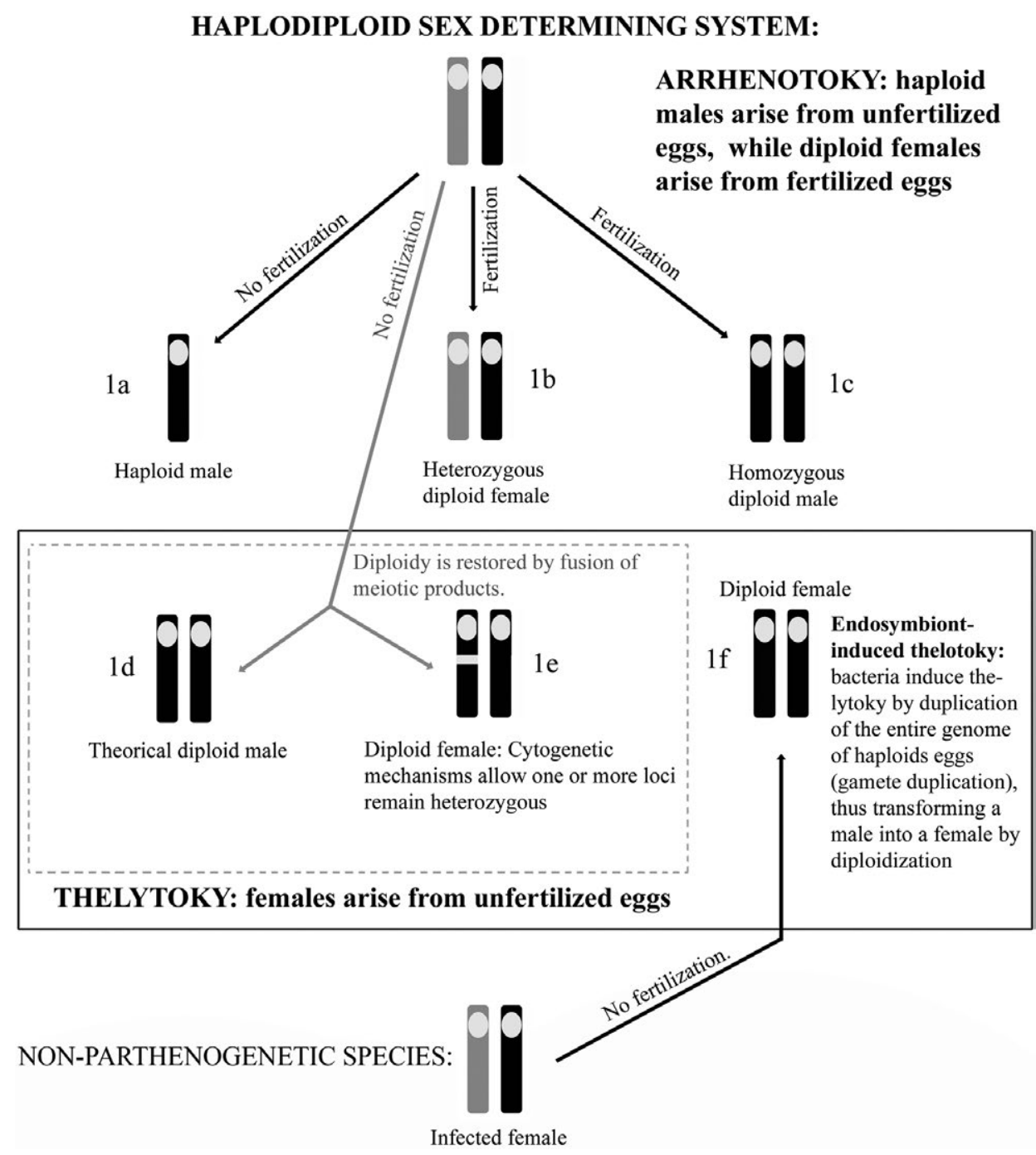

Fig. 1. Haplodiploid sex-determining system types present in most hymenopteran species, including ants, bees and wasps. There are two types of haplodiploid sex-determination system: Arrhenotoky is characterized because haploid males hatch from unfertilized eggs (1a) and diploid females hatch from fertilized eggs (1b). Following complementary sex determination system, theoretically males could appear if all loci remained homozygous (1c and 1d). On the other hand, thelytoky is characterized because females hatch from unfertilized eggs (1e). Microbial induced parthenogenesis (1f) could be considered as an "aberrant" thelytokous sex determination system, in which duplication of the whole genome of the haploid eggs allows the transformation of males into females.

Whiting (1961), sex is determined by the alleles at the sex locus. Diploid heterozygous individuals at this locus become females, homozygous individuals diploid males.

This model is apparently found in many organisms, including Hymenoptera species, with the exception of certain wasps. According to Cook (1993) and Hurst \& Peck (1996) the single locus determination model is not applicable in chalcidoid or cynipoid parasitoid wasps (Stouthamer, 1997). Sex determination of the hymenopterous parasitoid, Nasonia vitripennis (Walker) (Pteromalidae), for instance, does not involve CDS, but is probably determined by genomic imprinting (Heimpel \& de Boer, 2008).

Myrmicine harvester ants of the genus Messor are mainly distributed in the Palaearctic region (Bolton, 1982; Agosti, 1987; Cagniant, 1998; Schlick-Steiner et al., 2006), while $M$. barbarus and $M$. capitatus are mainly confined to the Mediterranean basin (Schlick-Steiner et al., 2006). The last Ice Age and post-glacial waves of advancing and retreating ice shaped the phylo-geographic structure of many species, including some ants such as Formica sp. (Goropashnaya et al., 2007). Pleistocene glaciations and expansion routes from different refuges have also been proposed to explain the distribution of Messor spp. in Central Europe (Schlick-Steiner et al., 2006).

Grasso et al. (2000) found that M. capitatus workers can produce female offspring in the absence of a queen. They also confirmed the appearance of males after several laboratory generations. Thelytoky has not been tested in Messor barbarus (L.). The taxonomy of the genus Messor is poorly resolved in European populations (LapevaGjonova et al., 2010). However, M. capitatus and M. barbarus belong to the same group (Cagniant, 1998). As far 
AUTOMICTIC PARTHENOGENESIS

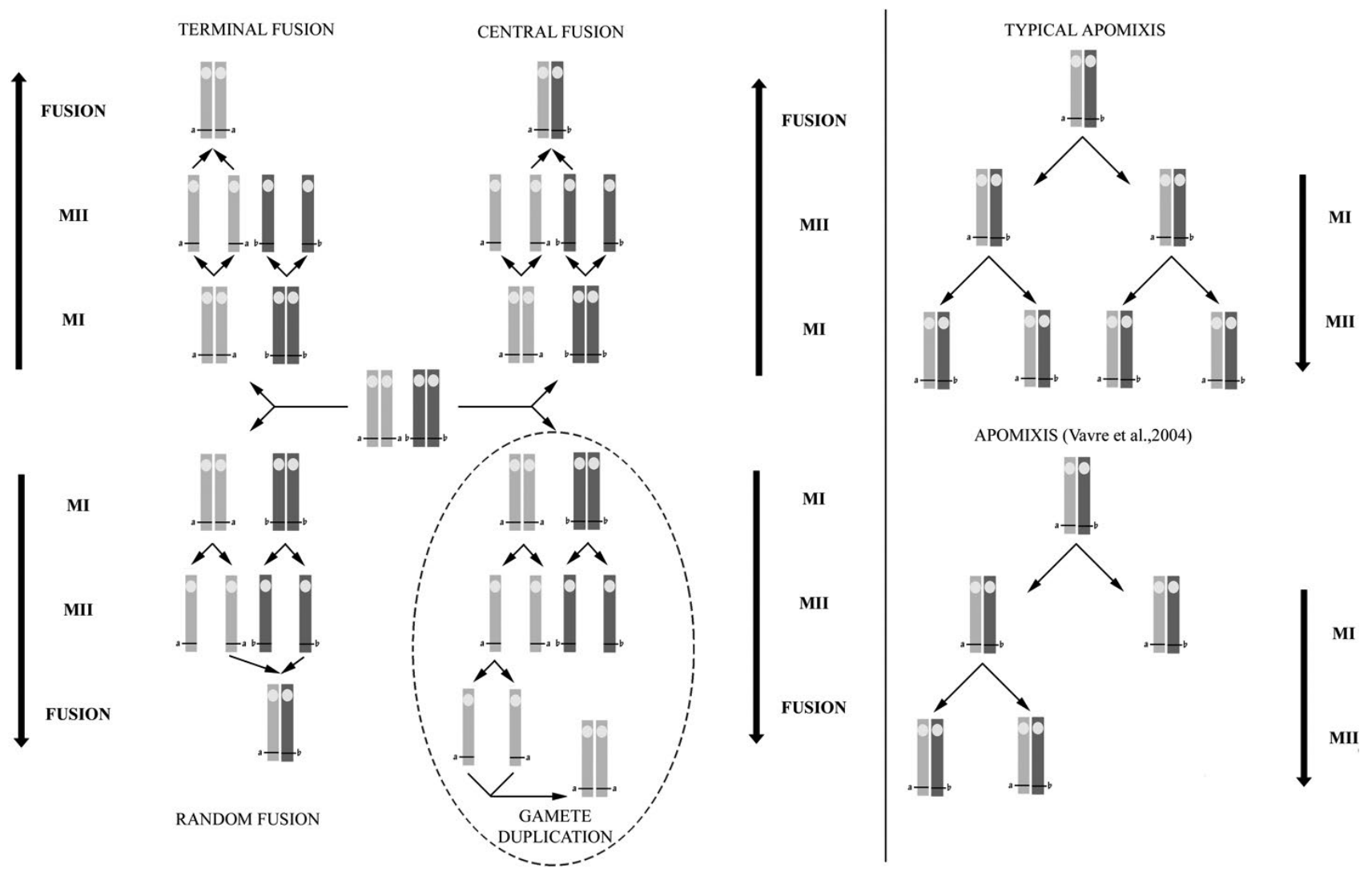

Fig. 2. Cytogenetic mechanisms leading to thelytokous diploidization due to meiotic and post-meiotic modifications. Note the different consequences in homozygosity or heterozygosity of embryos. Automictic parthenogenesis can be induced by terminal fusion, central fusion, random fusion or gamete duplication. A new variant of apomictic parthenogenesis has been described by Vavre et al. (2004). MI - meiosis I; MII - meiosis II.

as we are aware, no data exist about the reproductive system of M. barbarus.

The rickettsial bacteria Wolbachia is a maternallyinherited endosymbiont that induces reproductive alterations in many arthropods and nematodes (Werren, 1997). It is associated with male killing, male feminisation, cytoplasmic incompatibility (CI) and parthenogenesis induction (Werren et al., 1995, 2008; Serbus et al., 2008). Parthenogenesis induction occurs in distinct parasitoid wasps, where bacterial infection has been linked to their haplodiploid reproduction system (Breeuwer \& Werren, 1990; Cordaux et al., 2011). Wolbachia induces automictic parthenogenesis in some parasitoid wasps belonging to the genera Trichogramma, Aphytis, Encarsia, Leptopilina, and Muscidifurax. The bacterium manipulates the wasp's reproduction to produce mostly female offspring and thus guarantees its maternal transmission (Legner, 1987; Stouthamer \& Kazmer, 1994; Werren et al., 1995). Wolbachia cause "gamete duplication" (Fig. 2) restoring diploidy: a segregation failure in anaphase-I result in a homozygous diploid female (Stouthamer \& Kazmer, 1994). However, a new mechanism similar to apomictic parthenogenesis was reported by Vavre et al. (2004), who described Rickettsia-induced parthenogenesis in the wasp parasitoid Neochrysocharis formosa (Westwood) (Hymenoptera: Eulophidae), with meiosis replaced by a single equatorial division. The traditional cytological differences between bacteria-induced and non-induced thelytokous parthenogenesis should, in light of this, therefore be revised.

Other bacterial symbionts like Rickettsia have been proposed as parthenogenesis-inducing or inductors of reproductive distortion. Cardinium was the second bacterial lineage discovered to induce CI in arthropods, and the endosymbiotic bacteria Spiroplasma spp. are known to cause selective death of male offspring in insects (e.g. Hagimori et al., 2006; Giorgini et al., 2010). Other bacteria such as Serratia have also been reported as endosymbionts of wood ants, Formica cinerea (Mayr), as well as Wolbachia and Cardinium (Sirviö \& Pamilo, 2010). Endosymbionts that alter reproduction are considered to be highly important in the evolutionary history of social insects (ants, social bees and wasps), potentially interfering in the sex-ratio conflict between workers and queens (Lombardo, 2008; Sirviö \& Pamilo, 2010).

Wolbachia infection has been reported in several ant species (Wenseleers et al., 1998; Wenseleers \& Billen, 2000; Van Borm et al., 2001; Russell et al., 2009; Frost et al., 2010), although few studies have explored the possible role of bacteria in relation tothelytokous modes of reproduction. For example, Wenseleers \& Billen (2000) failed to detect Wolbachia in some of the reported thely- 
tokous species $[P$. punctate, C. biroi, P. pungens, $M$. capitatus, C. cursor, Cataglyphis piliscapus (Forel)], and did not test for other endosymbionts. In addition, inherited bacteria such as Wolbachia and Cardinium have been dismissed as factors inducing asexuality in M. smithii (Himler et al., 2009).

Grasso et al. (2000) excluded the influence of Wolbachia in thelytokous parthenogenesis in M. capitatus, but confirmed the thelytoky of workers, as previously reported in this harvesting ant (Grasso et al., 1998). These authors concluded that in this species, thelytoky has evolved independently of Wolbachia (A or B supergroups), certainly in the Italian populations examined. Additional Wolbachia supergroups have been reported since then, and further diagnostic bacterial genes have been sequenced, allowing better characterization in many cases, an important aspect given that a different sensitivity of PCR (polymerase chain reaction) primers for detecting Wolbachia can lead to false negative results (Hong et al., 2002; Marcon et al., 2011; Simoes et al., 2011). The Multilocus System Typing (MLST) (Baldo et al., 2006b) is a powerful methodology for checking possible Wolbachia infection. It allows for the checking of the DNA sequences of five distinct specific bacterial loci simultaneously, reveals the bacterial supergroup, and enables informative phylogenies to be constructed (Frost et al., 2010; Arthofer et al., 2011; Zhang et al., 2011).

Our objective in the present study was to test these new markers in Messor sp. in order to confirm the independence of thelytokous parthenogenesis in this ant genus from any kind of endosymbiotic bacterium. We also checked the possible role of other endosymbionts that could alter host reproduction in different ways. Rickettsia, Cardinium or Spiroplasma had not been previously screened in this insect. If present, they might be involved in its peculiar reproductive system (i.e. production of female offspring in the absence of a queen)

The study was conducted on Iberian populations of $M$. barbarus and $M$. capitatus to facilitate their comparison with the Italian populations analyzed by Grasso et al. $(1998,2000)$ as well as to test geographical differences in the bacterial infection due to the glacial refuge effect.

\section{MATERIAL AND METHODS}

\section{Field collections and DNA extraction}

More than 250 individuals of $M$. capitatus and M. barbarus were collected from different populations in Spain in 2010 (Table 1, Fig. 3). Individuals were stored in $100 \%$ ethanol prior to DNA extraction. After careful drying, each sample (a pool of 3-4 individuals from a given location) was homogenized in 300 $\mu \mathrm{L}$ of TNES buffer ( $50 \mathrm{mM}$ Tris- $\mathrm{HCl}, \mathrm{pH} 8.0 ; 400 \mathrm{mM} \mathrm{NaCl}$; $20 \mathrm{mM}$ EDTA, $\mathrm{pH} 8.0 ; 0.5 \%$ SDS) containing proteinase $\mathrm{K}$ $(0.03 \% \mathrm{w} / \mathrm{v})$ (Roche Applied Science, Indianapolis, IN, USA) and incubated overnight at $37^{\circ} \mathrm{C}$. Standard phenol/chloroform (Acros Organics, Thermo Fisher Scientific, Belgium) extraction followed by ethanol precipitation was used. The samples were dissolved in Tris-EDTA ( $1 \mathrm{mM}$ Tris-HCl, $\mathrm{pH} 8.0 ; 1 \mathrm{mM}$ EDTA, $\mathrm{pH}$ 8.0) and incubated with RNase A (Roche Applied Science) $(5 \mu \mathrm{g} / \mathrm{ml})$ for $2 \mathrm{~h}$ at room temperature. The final DNA concentration was $50 \mathrm{ng} / \mu \mathrm{L}$.
TABLE 1. Sampled populations of Messor capitatus and $M$. barbarus, of which a total of $n$ individuals were analysed.

\begin{tabular}{lcccc}
\hline Sample & Latitude & Longitude & Altitude & $n$ \\
\hline La Bañeza I & 266687 & 4692040 & 797 & 24 \\
La Bañeza III & 263733 & 4684441 & 788 & 20 \\
La Bañeza III & 253795 & 4682834 & 813 & 20 \\
Villalpando I & 305018 & 4643862 & 694 & 23 \\
Villalpando II & 299157 & 4637024 & 690 & 20 \\
Villalpando III & 294332 & 4626560 & 729 & 20 \\
Rueda I & 345498 & 4585536 & 762 & 21 \\
Rueda II & 336037 & 4586225 & 744 & 20 \\
Rueda III & 328714 & 4577869 & 685 & 20 \\
Sanchidrián I & 377110 & 4527770 & 1021 & 23 \\
Sanchidrián II & 367258 & 4529221 & 927 & 20 \\
Sanchidrián III & 358426 & 4525813 & 856 & 24 \\
\hline Total & & & & 255 \\
\hline
\end{tabular}

\section{Bacterial PCR detection}

Wolbachia was screened by PCR amplification of the Wolbachia's 16S rRNA gene sequence, using general forward and reverse primers (Zabal-Aguirre et al., 2010) and a second nested PCR amplification with $\mathrm{B}$ and $\mathrm{F}$ strain-specific primers (nested_FF: 5' TGA GCC TAT ATT AGA TTA GCT AGT TGG TAA G 3'; nested_FB: 5' GCC TAT ATT AGA TTA GCT AGT TGG TGG A $\overline{3}^{\prime}$; nested reverse: $5^{\prime}$ TAG TCC CCA GGC GGA ATG TT 3'). Reactions were performed in $25 \mu \mathrm{L}$ containing $2 \mathrm{mM}$ of $\mathrm{MgCl}_{2}, 0.2 \mathrm{mM}$ dNTPs, $1.2 \mu \mathrm{M}$ of each primer, 1.25 U BIOTAQ DNA polymerase (Bioline Reagents $\mathrm{Ltd}, \mathrm{UK})$ and $2 \mu \mathrm{L}$ of DNA solution $(50 \mathrm{ng} / \mu \mathrm{l})$. The detection threshold was tested with dilution series in order to determine the optimal genomic DNA concentration for PCR conditions. We estimated that $100 \mathrm{ng}$ of genomic DNA, added to a PCR reaction of $25 \mu \mathrm{L}$, allowed the detection of endosymbionts in our positive controls. Thermal cycling conditions were $30 \mathrm{~s}$ at $95^{\circ} \mathrm{C}$ (denaturing), followed by 35 cycles of $30 \mathrm{~s}$ at $95^{\circ} \mathrm{C}, 1 \mathrm{~min}$ at $54^{\circ} \mathrm{C}$ (annealing) (for the general $16 \mathrm{~S}$ rRNA gene primers), $69^{\circ} \mathrm{C}$ (for the $16 \mathrm{~S}$ rRNA gene-specific primers) and $1 \mathrm{~min}$ at $72^{\circ} \mathrm{C}$ (extension), and with a final elongation step of $10 \mathrm{~min}$ at $72^{\circ} \mathrm{C}$.

Multi-locus strain typing (MLST) and wsp amplification were performed as described by Baldo et al. (2006a) with modifications: PCR amplification was performed in a $50 \mu \mathrm{L}$ total volume of reaction mixture containing $2 \mathrm{mM}$ of $\mathrm{MgCl}_{2}, 0.2 \mathrm{mM}$ dNTPs, $1.2 \mu \mathrm{M}$ of each primers and $1.25 \mathrm{U}$ of BIOTAQ DNA polymerase. The thermal cycling conditions were incubation at $94^{\circ} \mathrm{C}$ for $10 \mathrm{~min}$, followed by 36 cycles of $30 \mathrm{~s}$ at $94^{\circ} \mathrm{C}, 45 \mathrm{~s}$ of $54^{\circ} \mathrm{C}$ for $h c p A$, gat $B$, fts $Z$ and cox $A$, and $59^{\circ} \mathrm{C}$ for $f b p A$ and $w s p$, and $72^{\circ} \mathrm{C}$ for $1.5 \mathrm{~min}$, a final elongation step at $70^{\circ} \mathrm{C}$ for $10 \mathrm{~min}$, and hold at $4^{\circ} \mathrm{C}$.

Spiroplasma infection was tested by PCR amplifying the 16S rRNA gene with specific primers Ha-In-1 (Hurst et al., 1999) and SP-ITS-N2 (Jiggins et al., 2000). Cardinium were analyzed using specific primers Ch_F and Ch_R (Zchori-Fein \& Perlman, 2004). Universal primers $27 \mathrm{f}$ and $1492 \mathrm{R}$ (Weisburg et al., 1991) were employed as additional controls to verify the presence of any other unknown endosymbionts, including Rickettsia sp., in the samples. PCR amplification was here performed in a total volume of $25 \mu \mathrm{L}$ containing $2 \mathrm{mM}$ of $\mathrm{MgCl}_{2}, 0.2 \mathrm{mM}$ dNTP, 1.2 $\mu \mathrm{M}$ of each primers, $1.25 \mathrm{U}$ BIOTAQ DNA polymerase and 2 $\mu \mathrm{L}$ of DNA solution $(50 \mathrm{ng} / \mu \mathrm{l})$. Thermal cycling conditions were incubation at $94^{\circ} \mathrm{C}$ for $10 \mathrm{~min}$, followed by 36 cycles of 30 $\mathrm{s}$ at $94^{\circ} \mathrm{C}, 1 \mathrm{~min}$ at $55^{\circ} \mathrm{C}$ (Spiroplasma $16 \mathrm{~S}$ rRNA gene and bacteria universal primers $16 \mathrm{~S}$ rRNA gene) or $58^{\circ} \mathrm{C}$ (Cardinium and Spiroplasma DNAse gene primers) and $1.5 \mathrm{~min}$ at $72^{\circ} \mathrm{C}$, a 


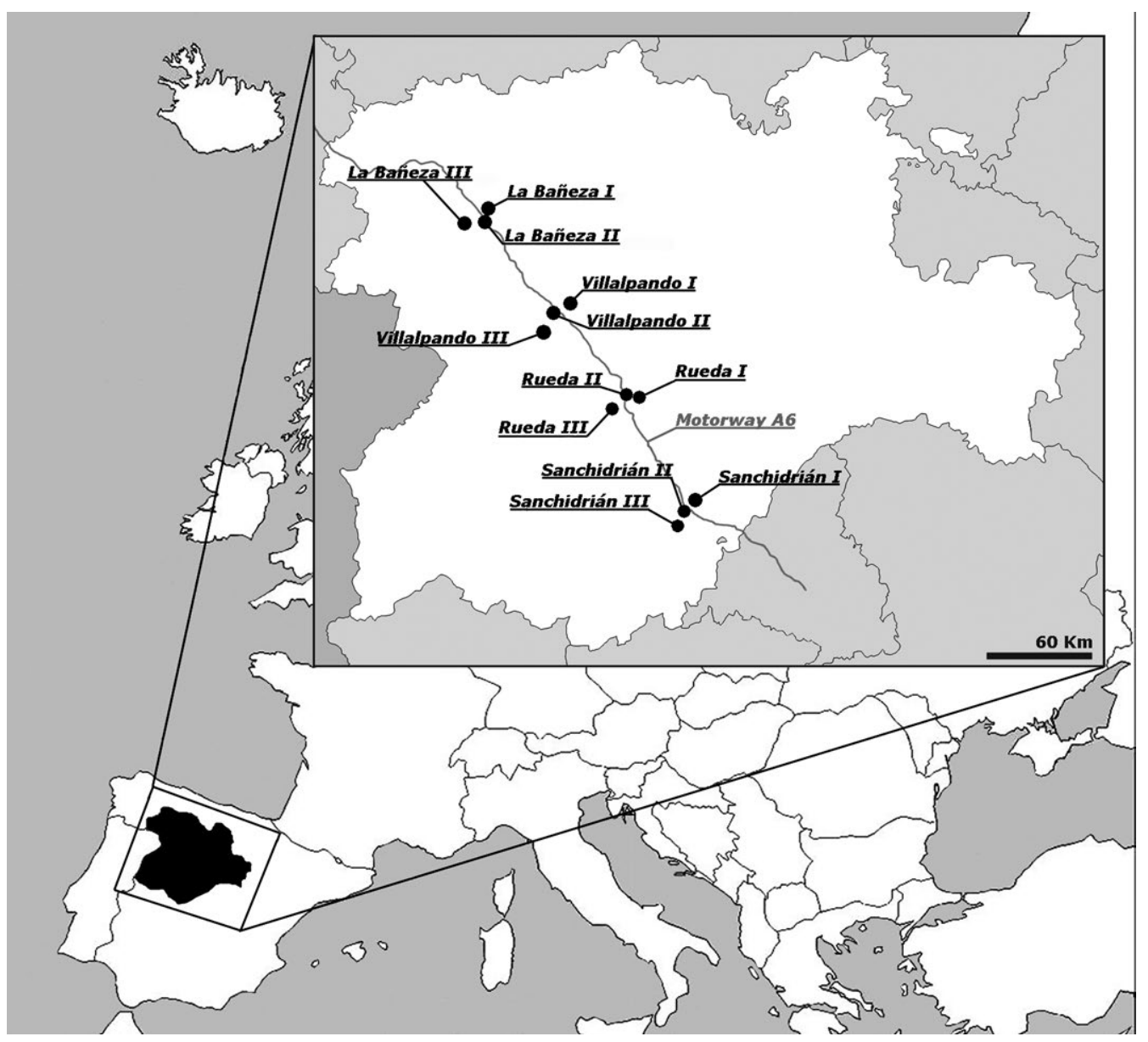

Fig. 3. Geographical distribution of the analyzed populations of Messor capitatus and M. barbarus.

final elongation step at $70^{\circ} \mathrm{C}$ for $10 \mathrm{~min}$, and hold at $4^{\circ} \mathrm{C} .10 \mu \mathrm{L}$ of each amplification product was separated electrophoretically on $0.7 \%$ agarose gel stained with ethidium bromide. Controls were run lacking DNA template. PCR products were purified by illustra GFX ${ }^{\mathrm{TM}}$ PCR DNA and Gel Band Purification Kit (GE Healthcare, Sacramento, CA, USA), whilst sequencing was performed by STAB VIDA (www.stabvida.com), Caparica, Portugal.

Positive and negative controls were run: DNA from Wolbachia and Spiroplasma infected individuals of the meadow grasshopper, Chorthippus parallelus (Zetterstedt) (Orthoptera: Acrididae) (Martinez et al., 2009) were employed as templates in positive controls for Wolbachia, Spiroplasma and Eubacteria PCR reactions. Because DNA from Cardinium-infected insects was not available, genomic DNA from a pool of non-identified spiders was instead used as a positive control, given that spiders are usually infected by this bacterium (S. Goodacre, pers. comm.). PCR conditions for Cardinium were as described by Zchori-Fein \& Perlman (2004). Cardinium was not found in any sequencing following Eubacteria PCR reactions.

DNA quality was tested by amplification of the ant's mtDNA gene Cox-1 (Lunt et al., 1998) and ITS1 from their rRNA gene (Parkin \& Butlin, 2004). Reactions were performed in a total volume of $50 \mu \mathrm{l}$ containing $2 \mathrm{mM}$ of $\mathrm{MgCl}_{2}, 0.2 \mathrm{mM}$ dNTPs, $1.2 \mu \mathrm{M}$ of each primers, $1.25 \mathrm{U}$ BIOTAQ DNA polymerase and $2 \mu \mathrm{l}$ of DNA template $(50 \mathrm{ng} / \mu \mathrm{l})$. Thermal cycling conditions were $30 \mathrm{~s}$ at $95^{\circ} \mathrm{C}$, followed by 39 cycles of $30 \mathrm{~s}$ at $95^{\circ} \mathrm{C}, 1 \mathrm{~min}$ at $56^{\circ} \mathrm{C}$ and $1 \mathrm{~min}$ at $72^{\circ} \mathrm{C}$, with a a final elongation step of 10 min at $72^{\circ} \mathrm{C}$.

\section{RESULTS AND DISCUSSION}

Ten individuals from each field colony were examined for Wolbachia infection using the above-mentioned PCR assays, but none were found to be infected. However, the amplified PCR products in all positive controls exclude the possibility of technical failure.

Wolbachia diversity has been proposed as a cause for such failures of detection because these bacteria have not always been successfully detected during PCR screening surveys (Sirviö \& Pamilo, 2010). However, we tested several pairs of primers (specific for 16S rRNA gene, five MLST loci and the wsp gene) to avoid this problem. The primers were designed to amplify any Wolbachia supergroup, but none of them detected Wolbachia. This result allows us to disregard with some degree of confidence the failure of PCR amplification to be due to an unknown Wolbachia strain infecting both Messor ant species here tested. These results thereby confirm that Wolbachia is not involved in parthenogenesis induction in Messor species, and is unlikely to be involved in any of the other previously described thelytokous ant species.

Several reasons have been proposed to explain why Wolbachia does not infect thelytokous ants. Hurst \& Peck's hypothesis (1996) supports that idea that Wolbachia-induced thelytoky would produce homozygous diploid offspring, which in Messor ant species 
would result in the production of diploid males (Fig. 1d), an impasse for Wolbachia maternal transmission (Stouthamer, 1997; Wenseleers \& Billen, 2000). This could explain why social Hymenoptera such as Messor sp. are not infected by the bacterium.

Wenseleers et al. (1998) proposed that the spread of Wolbachia infection could be difficult in monogynous ant colonies (like $M$. capitatus) but easier in polygynous species. In contrast, Shoemaker et al. (2000) argue that monogynous ant species (e.g. red imported fire ant, Solepnopsis invicta Buren) favour a high prevalence of Wolbachia, inducing cytoplasmic incompatibility. Recently, Sirviö \& Pamilo (2010) did not find any correlation between Wolbachia infection and the detected polymorphism of the wood ant, $F$. cinerea related to monogynous/polygynous colonies. Our results partially support Wenseleers et al.'s hypothesis. However, more studies are needed to test whether this social behavior is associated with Wolbachia infection. In addition, loss of Wolbachia infection in ants has been linked to population processes such as expansions and local population bottlenecks (Shoemaker et al., 2000; Reuter et al., 2004). Such stochastic means should be considered in $M$. capitatus and barbarus, whose recent natural history has been related to quaternary glaciations (Schlick-Steiner et al., 2006).

In our study, we also tested infection by other bacterial endosymbionts. Neither Cardinum nor Spiroplasma were detected in any sample, and Eubacteria PCR assays allowed us to disregard other potential endosymbionts. DNA quality assays (successful PCR amplification of ant ribosomal and mitochondrial genes) also allowed us to disregard any false negative PCR amplifications due to degraded DNA.

The bacterial genus Cardinium has recently been described, and includes species that manipulate host reproduction (Weeks \& Breeuwer, 2001; Hunter et al., 2003; Zchori-Fein \& Perlman, 2004). In species such as the false spider mite, Brevipalpus phoenicis (Acari: Trombidiformes: Tenuipalpidae), Cardinium induces thelytokous reproduction through the feminization of unfertilized eggs. Uninfected unfertilized eggs of $B$. phoenicis develop into haploid males (Weeks \& Breeuwer, 2001), thus making this genus a candidate for the induction of parthenogenesis in ants. Recently, Sirviö \& Pamilo (2010) detected low prevalence (1-2\%) of Cardinium in in the wood ant, $F$. cinerea. However, these are not detailed studies about the effect of this endosymbiont in the host. Even so, the low prevalence of this endosymbiont suggests a non-essential role in the biology of $F$. cinerea. Moreover, our own study indicates that Cardinium does not induce parthenogenesis in Messor capitatus. These data could question previous hypotheses about the role of these bacteria in ant sex ratio alterations.

Spiroplasma is another bacterial genus detected in several arthropods. Its most frequent host phenotype is related to male killing (Gasparich et al., 2004). In our study, Spiroplasma was tested with specific primers HaIn-1 (Hurst et al., 1999) and SP-ITS-N2 (Jiggins et al.,
2000), but these bacteria were not detected in our samples. Other Rickettsia spp. have been reported as bacteria that could manipulate the reproduction of their host and induce thelytokous parthenogenesis (AdachiHagimori et al., 2008). The universal PCR primers used in the present study disallow this possibility, as they should detect any endosymbiont species infecting Messor spp. In all samples, positive amplifications matched with environmental bacteria such as Pseudomonadales. Neither Rickettsia sp. nor any other endosymbionts were detected.

Tests for incidence of other unknown endosymbionts only yielded seven positives samples. While DNA sequences showed a high homology with Pseudomonas, Lactobacillus and other non-identified bacteria, no endosymbiont sequences were recorded. Environmental and human contamination are the most likely sources of these bacteria.

The incidence of reproductive endosymbionts is probably heavily underestimated in the scientific literature, considering the small number of individuals usually sampled from most species, which may fail to detect relatively rare infections, and also the low prevalence of endosymbionts in several species. For instance, only $1-2 \%$ of individuals of Formica cinerea were infected by Cardinium, including several uninfected populations (Sirviö \& Pamilo, 2010). These low proportions could be close to the sample and PCR error (Löfström et al., 2008). Thus, although a large number of individuals were tested in our study, the possibility of an extremely rare endosymbiont infecting $M$. capitatus and/or $M$. barbarus cannot be excluded.

Most species reproduce sexually. Because asexual reproduction is rare (Simon et al., 2003), many theories about the paradox of sex have been proposed to explain the advantages of sex against its cost and inefficiency (Agrawal, 2009; Birky \& Barraclough, 2009). Various selected forces have been proposed as explanations for thelytokous parthenogenesis in ants, which appear in different subfamilies. For instance, asexual lineages could colonize new habitats and food sources more easily than related sexual species (Williams, 1975; Maynard, 1978; Bell, 1982). In this case, however, the role of endosymbionts can be excluded definitively.

ACKNOWLEDGEMENTS. We are grateful to J. Benyei and $\mathrm{H}$. Loxdale for reviewing and improving the English draft of this manuscript. We also wish to thank to F. Arroyo-Yebras for her help in the lab. This work was supported by Spanish government grants CGL2009-08380/BOS and CICYT (CGL201124871), with the collaboration of Chromacell S.L.

\section{REFERENCES}

Adachi-Hagimori T., Miura K. \& Stouthamer R. 2008: A new cytogenetic mechanism for bacterial endosymbiont-induced parthenogenesis in Hymenoptera. — Proc. R. Soc. Lond. (B) 275: 2667-2673.

Agosti D. 1987: A provisional list of the Balkan ants (Hym. Formicidae) with a key to the worker caste. II. Key to the worker caste, including the European species without the Iberian. - Mitt. Schweiz. Entomol. Ges. 60: 261-293. 
Agrawal A.F. 2009: Differences between selection on sex versus recombination in red queen models with diploid hosts. - Evolution 63: 2131-2141.

Arthofer W., Riegler M., Schuler H., Schneider D., Moder K., Miller W.J. \& Stauffer C. 2011: Allele intersection analysis: A novel tool for multi locus sequence assignment in multiply infected hosts. - PloS One 6: e22198.

Baldo L., Bordenstein S., Wernegreen J.J. \& Werren J.H. 2006a: Widespread recombination throughout Wolbachia genomes. - Mol. Biol. Evol. 23: 437-449.

Baldo L., Hotopp J.C.D., Jolley K.A., Bordenstein S., Biber S.A., Choudhury R.R., Hayashi C., Maiden M.C.J., Tettelin H. \& Werren J.H. 2006b: Multilocus sequence typing system for the endosymbiont Wolbachia pipientis. - Appl. Environ. Microbiol. 72: 7098-7110.

Bell G. 1982: The Masterpiece of Nature: The Evolution and Genetics of Sexuality. University of California Press, Berkeley, $635 \mathrm{pp}$.

Birky C.W. \& Barraclough T.G. 2009: Asexual speciation. In Schon K. \& Van Dijk P. (eds): Lost Sex: The Evolutionary Biology of Parthenogenesis. Springer, Heidelberg, pp. 201-216.

Bolton B. 1982: Afrotropical species of the myrmicine ant genera Cardiocondyla, Leptothorax, Melissotarsus, Messor and Cataulacus (Formicidae). — Bull. Br. Mus. Nat. Hist. (Entomol.) 45: 307-370.

Breeuwer J.A.J. \& WerRen J.H. 1990: Microorganisms associated with chromosome destruction and reproductive isolation between two insect species. - Nature 346: 558-560.

Cagniant H. 1998: Le genre Messor au Maroc (Hymenoptera: Formicidae). — Ann. Soc. Entomol. Fr. (N.S.). 33: 419-434.

Cook J.M. 1993: Sex determination in the Hymenoptera: a review of models and evidence. - Heredity 71: 421-435.

Cordaux R., Bouchon D. \& Greve P. 2011: The impact of endosymbionts on the evolution of host sex-determination mechanisms. - Trends Genet. 27: 332-341.

Foucaud J., Fournier D., Orivel J., Delabie J.H.C., Loiseau A., Le Breton J., Kergoat G.J. \& Estoup A. 2007: Sex and clonality in the little fire ant. — Mol. Biol. Evol. 24: 2465-2473.

Fournier D. \& Aron S. 2009: Evolution: No-male's land for an Amazonian ant. - Curr. Biol. 19: R738-R740.

Fournier D., Estoup A., Orivel J., Foucaud J., Jourdan H., Le Breton J. \& LE Keller L. 2005: Clonal reproduction by males and females in the little fire ant. - Nature 435: 1230-1234.

Frost C.L., Fernandez-Marin H., Smith J.E. \& Hughes W.O.H. 2010: Multiple gains and losses of Wolbachia symbionts across a tribe of fungus-growing ants. - Mol. Ecol. 19: 4077-4085.

Gasparich G.E., Whitcomb R.F., Dodge D., French F.E., Glass J. \& Williamson D.L. 2004: The genus Spiroplasma and its non-helical descendants: phylogenetic classification, correlation with phenotype and roots of the Mycoplasma mycoides clade. - Int. J. Syst. Evol. Microbiol. 54: 893-918.

Giorgini M., Bernardo U., Monti M.M., Nappo A.G. \& Gebiola M. 2010: Rickettsia symbionts cause parthenogenetic reproduction in the parasitoid wasp Pnigalio soemius (Hymenoptera: Eulophidae). — Appl. Environ. Microbiol. 76: 2589-2599.

Goropashnaya A., Fedorov V., Seifert B. \& Pamilo P. 2007: Phylogeography and population structure in the ant Formica exsecta (Hymenoptera, Formicidae) across Eurasia as reflected by mitochondrial DNA variation and microsatellites. - Ann. Zool. Fenn. 44: 462-474.
Grasso D.A., Mori A., Le Mou F., Giovannotti M. \& Fanfani A. 1998: The stridulatory organ of four Messor ant species (Hymenoptera, Formicidae). - Ital. J. Zool. 65: 167-174.

Grasso D.A., Wenseleers T., Mori A., Le Moli F. \& Billen J. 2000: Thelytokous worker reproduction and lack of Wolbachia infection in the harvesting ant Messor capitatus. Ethol. Ecol. Evol. 12: 309-314.

Hagimori T., Abe Y., Date S. \& Kazuki M. 2006: The first finding of a Rickettsia bacterium associated with parthenogenesis induction among insects. - Curr. Microbiol. 52: 97-101.

Heimpel G.E. \& De Boer J.G. 2008: Sex determination in the Hymenoptera. - Annu. Rev. Entomol. 53: 209-230.

Himler A.G., Caldera E.J., Baer B.C., Fernández-Marín H. \& Mueller U.G. 2009: No sex in fungus-farming ants or their crops. - Proc. R. Soc. Lond. (B) 276: 2611-2616.

Hong X.Y., Gotoh T. \& NodA H. 2002: Sensitivity comparison of PCR primers for detecting Wolbachia in spider mites. Appl. Entomol. Zool. 37: 379-383.

Hunter M.S., Perlman S.J. \& Kelly S.E. 2003: A bacterial symbiont in the Bacteroidetes induces cytoplasmic incompatibility in the parasitoid wasp Encarsia pergandiella. - Proc. R. Soc. Lond. (B) 270: 2185-2190.

Hurst L.D. \& PeCK J.R. 1996: Recent advances in understanding of the evolution and maintenance of sex. - Trends Ecol. Evol. 11: 46-52.

Hurst G.D.D., Von Der Schulenburg J.H.G., Majerus T.M.O., Bertrand D., ZaKharov I.A., BaungaArd J., VölkL W., Stouthamer R. \& Majerus M.E.N. 1999: Invasion of one insect species, Adalia bipunctata, by two different malekilling bacteria. - Insect Mol. Biol. 8: 133-139.

Itow T., Kobayashi K., Kubota M., Ogata K., Imai H. \& CROzIER R. 1984: The reproductive cycle of the queenless ant Pristomyrmex pungens. - Insectes Soc. 31: 87-102.

Jiggins F.M., Hurst G.D., Jiggins C.D., v. D. Schulenburg J.H. \& Majerus M.E. 2000: The butterfly Danaus chrysippus is infected by a male-killing Spiroplasma bacterium. - Parasitology 120: 439-446.

Kronauer D.J.C., Pierce N.E. \& Keller L. 2012: Asexual reproduction in introduced and native populations of the ant Cerapachys biroi. — Mol. Ecol. 21: 5221-5235.

Lapeva-Guonova A., Antonova V., Radchenko A. \& Atanasova M. 2010: Catalogue of the ants (Hymenoptera, Formicidae) of Bulgaria. - Zookeys 62: 1-124.

LEGNER E.F. 1987: Transfer of thelytoky to arrhenotokous. Muscidifurax raptor Girault and Sanders (Hymenoptera: Pteromalidae). - Can. Entomol. 119: 265-271.

LeNOIR A. \& CAGNIANT H. 1986: Role of worker thelytoky in colonies of the ant Cataglyphis cursor (Hymenoptera: Formicidae). — Entomol. Gener. 11: 153-157.

LöFström C., Axelsson C. \& RÅdström P. 2008: Validation of a diagnostic PCR method for routine analysis of Salmonella spp. in animal feed samples. — Food Anal. Meth. 1: 23-27.

LomBARDo M. 2008: Access to mutualistic endosymbiotic microbes: an underappreciated benefit of group living. Behav. Ecol. Sociobiol. 62: 479-497.

Lunt D., Ibrahim K. \& Hewitt G. 1998: mtDNA phylogeography and postglacial patterns of subdivision in the meadow grasshopper Chorthippus parallelus. - Heredity $\mathbf{8 0}$ : 633-641.

Marcon H.S., Coscrato V.E., Selivon D., Paranhos-Perondini A.L. \& MARINO C.L. 2011: Variations in the sensitivity of different primers for detecting Wolbachia in Anastrepha (Diptera: Tephritidae). — Brazil. J. Microbiol. 42: 778-785. 
Martinez P., Del Castillo P. \& Bella J.L. 2009: Cytological detection of Wolbachia in squashed and paraffin embedded insect tissues. - Biotech. Histochem. 84: 347-353.

Maynard S. 1978: The Evolution of Sex. Cambridge University Press, Cambridge, $236 \mathrm{pp}$.

OhKawara K., Nakayama M., Sato A., Trindl A. \& Heinze J. 2006: Clonal reproduction and genetic caste differences in a queen-polymorphic ant, Vollenhovia emeryi. - Biol. Lett. 2: 359-363.

Oкамото M. \& OhKawara K. 2009: Conditional mating tactics in queen of inquiline ant Vollenhovia nipponica. - Ethol. Ecol. Evol. 21: 137-146.

PARKIN E.J. \& ButLIN R.K. 2004: Within- and betweenindividual sequence variation among ITS1 copies in the meadow grasshopper Chorthippus parallelus indicates frequent intrachromosomal gene conversion. - Mol. Biol. Evol. 21: $1595-1601$.

Pearcy M., Aron S., Doums C. \& Keller L. 2004: Conditional use of sex and parthenogenesis for worker and queen production in ants. - Science 306: 1780-1783.

Pearcy M., Hardy O. \& Aron S. 2006: Thelytokous parthenogenesis and its consequences on inbreeding in an ant. Heredity 96: 377-382.

Rabeling R. \& Kronauer D.J.C. 2013: Thelytokous parthenogenesis in eusocial Hymenoptera. - Annu. Rev. Entomol. 58: 273-292.

Rabeling C., Gonzales O., Schultz T., Bacci M., Garcia M.V.B., VerhaAgh M., Ishak H.D. \& Mueller U.G. 2011: Cryptic sexual populations account for genetic diversity and ecological success in a widely distributed, asexual fungusgrowing ant. — Proc. Nat. Acad. Sci. 108: 12366-12371.

Reuter M., Pedersen J.S. \& Keller L. 2004: Loss of Wolbachia infection during colonisation in the invasive Argentine ant Linepithema humile. - Heredity 94: 364-369.

Rey O., Loiseau A., Facon B., Foucaud F., Orivel J., Cornuet J., Robert S., Dobigny G., Delabie J.H.C., Ferreria Mariano C.S. \& Estoup A. 2011: Meiotic recombination dramatically decreased in thelytokous queens of the little fire ant and their sexually produced workers. - Mol. Biol. Evol. 28: 2591-2601.

Russell J.A., Moreau C.S., Goldman-Huertas B., Fujiwara M., LOHMAN D.J. \& PIERCE N.E. 2009: Bacterial gut symbionts are tightly linked with the evolution of herbivory in ants. Proc. Nat. Acad. Sci. U.S.A. 106: 21236-21241.

SCHILder K., Heinze J. \& Hölldobler B. 1999: Colony structure and reproduction in the thelytokous parthenogenetic an Platythyrea punctata (F. Smith) (Hymenoptera: Formicidae). - Insectes Soc. 46: 150-158.

Schlick-Steiner B.C., Steiner F.M., Konrad H. \& Markó B. 2006: More than one species of Messor harvester ants (Hymenoptera: Formicidae) in Central Europe. - Eur. J. Entomol. 103: 469-476.

Serbus L.R., Casper-Lindley C., Landmann F. \& Sullivan W. 2008: The genetics and cell biology of Wolbachia-host interactions. - Annu. Rev. Genet. 42: 683-707.

Shoemaker D., Ross K., Keller L., Vargo E. \& Werren J. 2000: Wolbachia infections in native and introduced populations of fire ants (Solenopsis spp.). - Insect Mol. Biol. 9: 661-673.

Simoes P.M., Mialdea G., Reiss D., Sagot M.F. \& Charlat S. 2011: Wolbachia detection: an assessment of standard PCR Protocols. - Mol. Ecol. Res. 11: 567-572.

Simon J.C., Delmotte F., Rispe C. \& Crease T. 2003: Phylogenetic relationships between parthenogens and their sexual relatives: the possible routes to parthenogenesis in animals. - Biol. J. Linn. Soc. 79: 151-163.

Sirviö A. \& PAmilo P. 2010: Multiple endosymbionts in populations of the ant Formica cinerea. - BMC Evol. Biol. 10: 335-347.

Stouthamer R. 1997: Wolbachia-induced parthenogenesis. In O’Neill S.L., Hoffmann A.A. \& Werren J.H. (eds): Influential Passengers: Inherited Microorganisms and Arthropod Reproduction. Oxford University Press, Oxford, pp. 102-122.

Stouthamer R. \& Kazmer D. 1994: Cytogenetics of microbeassociated parthenogenesis and its consequences for gene flow in Trichogramma wasps. - Heredity 73: 317-327.

TsusI K. 1988: Obligate parthenogenesis and reproductive division of labor in the Japanese queenless ant Pristomyrmex pungens: Comparison of intranidal and extranidal workers. Behav. Ecol. Sociobiol. 23: 247-255.

Van Borm S., Wenseleers T., Billen J. \& Boomsma J.J. 2001: Wolbachia in leafcutter ants: a widespread symbiont that may induce male killing or incompatible matings. - J. Evol. Biol. 14: $805-814$.

Vavre F., De Jong J.H. \& Stouthamer R. 2004: Cytogenetic mechanism and genetic consequences of thelytoky in the wasp Trichogramma cacoeciae. - Heredity 93: 592-596.

WeEKS A.R. \& BReEuwer J.A.J. 2001: Wolbachia-induced parthenogenesis in a genus of phytophagous mites. - Proc. $R$. Soc. Lond. (B) 268: 2245-2251.

Weisburg W., Barns S., Pelletier D. \& Lane D. 1991: 16S ribosomal DNA amplification for phylogenetic study. $-J$. Bacteriol. 173: 697-703.

Wenseleers T. \& Billen J. 2000: No evidence for Wolbachiainduced parthenogenesis in the social Hymenoptera. $-J$. Evol. Biol. 13: 277-280.

Wenseleers T., Ito F., Van Borm S., Huybrechts R., VOlCKAERT F. \& Billen J. 1998: Widespread occurrence of the micro-organism Wolbachia in ants. -Proc. R. Soc. Lond. (B) 265: 1447-1452.

WERREN J.H. 1997: Biology of Wolbachia. - Annu. Rev. Entomol. 42: 587-609.

WerRen J.H., Zhang W. \& Guo L.R. 1995: Evolution and phylogeny of Wolbachia - reproductive parasites of arthropods. - Proc. R. Soc. Lond (B) 261: 55-63.

WerRen J.H., Baldo L. \& Clark M.E. 2008: Wolbachia: master manipulators of invertebrate biology. - Nat. Rev. Microbiol. 6: $741-751$.

White M.J.D. 1984: Chromosomal mechanisms in animal reproduction. Boll. Zool. 51: 1-23.

Whiting A.R. 1961: Genetics of Habrobracon. - Adv. Genet. 10: $295-348$.

Williams G. 1975: Sex and Evolution. Princeton University Press, Princeton, $210 \mathrm{pp}$.

Zabal-Aguirre M., Arroyo F. \& Bella J.L. 2010: Distribution of Wolbachia infection in Chorthippus parallelus populations within and beyond a Pyrenean hybrid zone. - Heredity 104: 174-184

Zchori-Fein E. \& Perlman S.J. 2004: Distribution of the bacterial symbiont Cardinium in arthropods. - Mol. Ecol. 13: 2009-2016.

Zhang X., NorRis D.E. \& RASGON J.L. 2011: Distribution and molecular characterization of Wolbachia endosymbionts and filarial nematodes in Maryland populations of the lone star tick (Amblyomma americanum). - FEMS Microbiol. Ecol. 77: $50-56$.

Received June 29, 2012; revised and accepted November 26, 2012 